\title{
Establishing the hematopoietic stem cell transplant (HSCT) in a developing country; the journey of HSCT in Semarang, Indonesia
}

\author{
Damai Santosa $\mathbb{D}^{1} \cdot$ Eko Adhi Pangarsa ${ }^{1} \cdot$ Budi Setiawan $\mathbb{D}^{1} \cdot$ Ridho M. Naibaho $\mathbb{D}^{2} \cdot$ Daniel Rizky $\mathbb{D}^{1} \cdot$ \\ Edi Dharmana $\mathbb{1}^{3} \cdot$ Catharina Suharti $\mathbb{1}^{1}$
}

Received: 26 April 2020 / Revised: 26 May 2020 / Accepted: 4 June 2020 / Published online: 17 June 2020

(c) The Author(s) 2020. This article is published with open access

\section{To the Editor:}

Bone marrow transplantation (BMT) is a life-saving treatment for many incurable diseases. BMT presents a valid treatment option for many congenital and acquired disorders of the hematopoietic system, including several hematological malignancies [1-4]. In BMT, failing bone marrow is supplemented by hematopoietic stem cells derived from peripheral or umbilical cord blood; therefore, BMT may also be described as hematopoietic stem cell transplantation (HSCT) [5].

Indonesia has a long involvement with BMT services. In 1987, the first allogeneic and autologous BMTs in Indonesia were performed in Semarang, Central Java by Telogorejo Hospital and Dr. Kariadi General Hospital. These transplants were performed for several cases of acute myeloid leukemia (AML), chronic myeloid leukemia (CML), and thalassemia [6]; two of the cases of AML treated in Semarang in 1987 are still in remission. Two year later in 1989, Dr. Cipto Mangunkusumo Hospital in Jakarta performed several BMTs for CML, AML, ALL cases [7]. In 1989, Dr. Kariadi General Hospital, in collaboration with Dr. Sarjito Hospital in Jogyakarta, performed BMT for a patient with AML. Then, in 1991, Hasan Sadikin Hospital in Bandung, in collaboration with Telogorejo Hospital, performed an autologous BMT for a case of AML

Damai Santosa

santosaiva@yahoo.com

1 Division of Hematology/Medical Oncology, Department of Internal Medicine, Medical Faculty of Diponegoro University and Dr. Kariadi Hospital, Semarang, Indonesia

2 Division of Hematology/Medical Oncology, Department of Internal Medicine, Medical Faculty of Mulawarman University, Parikesit General Hospital, Tenggarong, Indonesia

3 Department of Parasitology, Medical Faculty of Diponegoro University, Semarang, Indonesia and the patient survived for 3 years. However, none of these efforts resulted in a sustained and effective Indonesian BMT.

Semarang is the capital of Central Java Province, Indonesia. It has an area of $373,78 \mathrm{~km}^{2}$ and a population of $\sim 1,729,428$ [8]. There are 7 public hospitals and 12 private hospitals in this city, with Dr. Kariadi Hospital being the city's National Referral Hospital [9].

In 2012, Dr. Kariadi Hospital committed to establishing a modern BMT. Steps taken towards achieving this goal comprised of: [1] developing a Road Map for BMT services [2]; formalizing collaborative international partnerships; [3] developing appropriate clinical and laboratory infrastructure [4]; increasing human resources capacity [5]; developing clinical teamwork; and [6] fostering pharmacy services.

Our team started with creating a policy framework for BMT procedures. This framework, our Road Map, is shown in Fig. 1. We began by holding BMT meetings to increase knowledge and skill for nurses, technicians, and doctors. Then, in collaboration with Singapore's National University Hospital (NUH), one doctor, two nurses, and one analyst were sent to NUH's BMT unit. They studied BMT-specific clinical capacities, apheresis, specific clinical nursing, and stem cell processing. One clinical pathologist was also trained in Dr. Soetomo Hospital in Surabaya in stem cell processing. Next, we invited a group known as the $\mathrm{C} 2 \mathrm{C}$ Foundation to improve our team's knowledge about BMT for thalassemia cases; this project involved 16 doctors and 37 nurses. Then, in 2012 and 2014, in a preceptorship program run in collaboration with the i-CML Foundation, we sent a doctor to Royal Adelaide Hospital (RAH) in South Australia to study CML management and BMT services.

Our short storage protocol calls for the suitable stem cells to be processed with RPMI, gentamicin, free preservative heparin, and held at $4{ }^{\circ} \mathrm{C}$ for a maximum of $72 \mathrm{~h}$. For long term storage, we deep freeze our samples to $-80^{\circ} \mathrm{C}$ after processing it with DMSO 5\% [10,11]. Total Nucleated 
Fig. 1 The BMT services was started in 2012 with autologous bone marrow transplant. Apharesis machine was available in 2013. In 2015, Dr. Kariadi Hospital has been accredited by Joint Committee International (JCI); and followed by BMT services in 2018 .

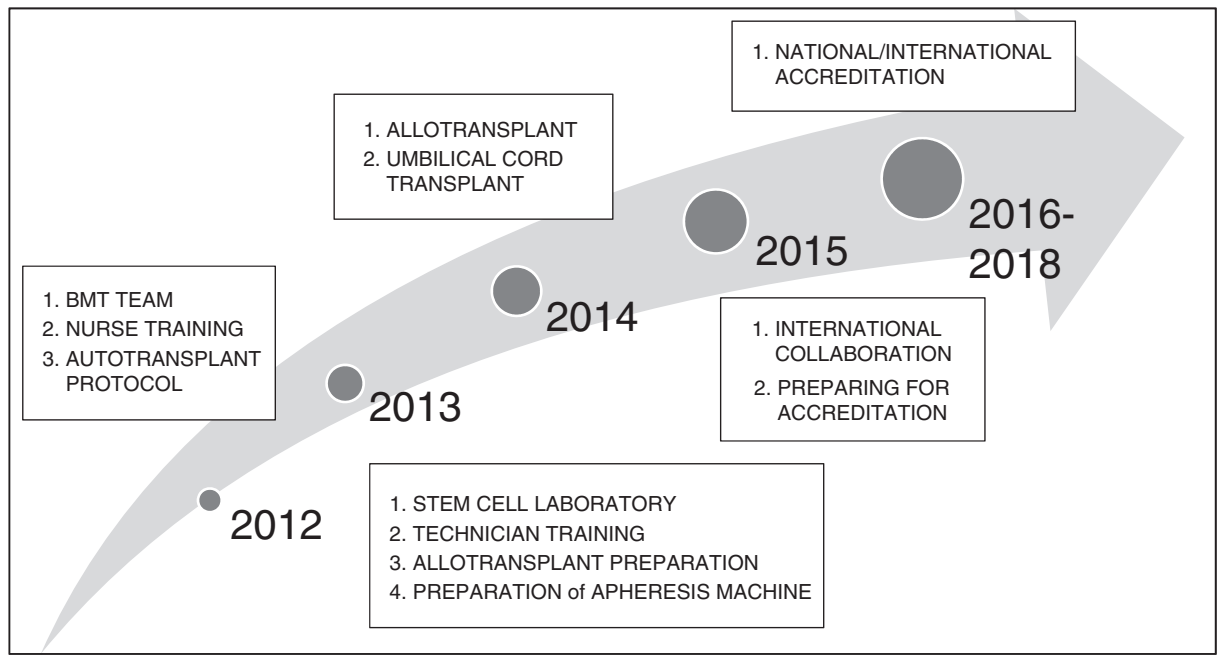

Cell and CD 34+ count is measured during harvest, postharvest, and post thawing/before infusion. The laboratory equipments used are a Class II Biosafety Cabinet, Refrigerator $\left(4^{\circ} \mathrm{C}\right)$, Freezer $\left(-20^{\circ} \mathrm{C}\right)$, low-temperature freezer $\left(-70\right.$ to $\left.-85^{\circ} \mathrm{C}\right)$, and water bath. $\mathrm{CD} 34+$ enumeration is calculated with a single platform by FACS Canto II $[12,13]$.

Our BMT team consists of a hematologist-medical oncologist, dentist, cardiologist, pulmonologist, clinical pathologist, clinical microbiologist, infectious-disease specialist, psychologist, and psychiatrist. Every Wednesday we hold a BMT meeting to share knowledge, skill, support management, and clinical approach. Our clinical pharmacist supplies and evaluates the adverse event of medications.

Today we have ten positive pressure rooms with HEPA filters; six rooms are located in the Kasuari Oncology Cancer Center and four rooms are in the Rajawali building. By 2018, we had already performed 16 HSCTs, including 2 allogeneic transplants. Diagnoses of the subjects receiving HSCT included AML, multiple myeloma, relapsed nonHodgkin Lymphoma (NHL), relapsed AML, and myelodysplastic syndrome (MDS). The donor source of the allogeneic transplants were siblings. Baseline patient characteristics and transplant data of our autologous and allogeneic patients are listed in Table 1.

No severe adverse events were reported at thawing (for example, clump formation). Grade 1 transient reactions, according to Common Terminology Criteria for Adverse Events (CTCAE criteria) [14] were recorded during reinfusion of cryopreserved cells (flushing, headache, hypertension, hemoglobinuria, bradycardia, shivering, and fever; the incidence of these reactions were 7, 6, 5, 5, 2, 2 , and 1 , respectively). The allogeneic transplant was performed in two patients with the full match from their siblings. Two autologous (two cases of relapsed NHL) and two allogeneic (relapsed AML and MDS)
Table 1 Baseline patient characteristics and transplant data of our autologous and allogeneic patients.

\begin{tabular}{lll}
\hline Characteristics & Autologous & Allogeneic \\
\hline Total & 14 & 2 \\
Age, median (IQR) & $43.5(18-62)$ & $31.3(24-39)$ \\
Gender: Male/Female & $9 / 5$ & $0 / 2$ \\
Indication & Multiple myeloma, & MDS \\
& AML, Relapsed NHL & Relapsed AML \\
Stem cell source & Peripheral blood & Peripheral blood \\
& Bone marrow & \\
Stem cell (CD34+) & $3.21(1.25-6.80)$ & 3.58 (2.91-4.26) \\
dose (median, IQR) & & \\
Donor & Not applicable & All siblings \\
HLA matching & & Fully match \\
\hline
\end{tabular}

$H L A$ human leukocyte antigen, $I Q R$ interquartile range, $N H L$ nonHodgkin lymphoma, $A M L$ acute myeloid leukemia.

patients died during the procedure due to transplant-related mortality [15].

Every patient except one achieved neutrophil and platelet engraftment, at a median of day +13 and day +15 , respectively. The most common serious adverse events during the transplantation were mucositis, nausea vomitus, neutropenia, sepsis, diarrhea, hair loss, electrolyte imbalance, anemia, thrombocytopenia, and febrile neutropenia. Hyperpigmentation developed at patient with myeloma given high dose melphalan.

Prophylaxis with ciprofloxacin, acyclovir, ganciclovir, fluconazole, and trimethoprim were given according to the protocol to reduce the risk of infection. The blood cultures in our patients with febrile neutropenia were generally found to be negative for aerobes, anaerobes, and fungal microorganisms; however, positive cultures for Escherichia coli, Pseudomonas aeruginosa, and Klebsiella pneumonia were achieved. Patients with 
febrile neutropenia were treated according to the guidelines [16, 17]. The overall survival rates 3 months, 6 months, and 1-year post-treatment were $56.25 \%$, $56.25 \%$, and $50 \%$, respectively.

Supportive treatments, including blood component transfusion, were given according to guidelines, and all blood products were treated with a single dose of radiation at $15-25$ Gy. Patients being treated according to our BMT protocol are treated with filtered and irradiated blood products. Irradiated products are cytomegalovirus-safe, have a reduced risk of nonhemolytic febrile transfusion and alloimmunization, and have a reduced incidence of transfusion-associated graft vs host disease in at-risk individuals [18-21].

We have pioneered a bone marrow donor's program called "Transformer", which consists of 30 volunteers who have been HLA typed. We also receive support from nonprofit organizations including the Hematology and Thalassemia Foundation and the Indonesian Cancer Foundation. To improve our BMT program further, we need to utilize every support we can. Of particular importance is continuing to strengthen our donor program, through means including the training of our human resources, developing our systems further, website design, and increasing the number of our volunteers [22, 23].

Indonesia's Ministry of Health has developed several health funding initiatives, including the National Health Insurance Program, the Healthcare and Social Security Agency, and the Indonesian Health Card. National Health Insurance covers over $81 \%$ of Indonesian citizens. Our BMT service is already listed in the national healthcare insurance system with a limited budget $( \pm 7005.60$ USD) [24]. We need to advocate and collaborate with the Ministry of Health in the future to improve and resolve this financial constraint.

Acknowledgements The authors thank Ag. Sumantri, MD; Moedrik Tamam, MD; Bambang Sudarmanto, MD; Muji Rahayu MD; Nyoman Suci Widyastiti, MD, Ph.D.; Herniah AW. MD; Ria Triwardhani, MD; Dian Widyaningrum, MD; Hendro Wahjono, MD; Agus Suryanto, MD; Darwito, MD, Ph.D.; Agoes Oerip, MD and Mika L. Tobing, MD for their supports in early initiation of BMT unit. Thanks to Koh Liang Piu, MD; Tan Lip Kun, MD; Lim Zi Yi, MD from NUH, Singapore. Thanks to Lawrence F, MD from C2C Foundation, Italia. Thank to Timothy Hughes, MD from RAH, Australia. Thank you to Callum Hammond, from the University of Auckland, New Zealand for the final review of this manuscript. The authors are also grateful to all the nurses, technicians, administrative staff, and especially for all the patients.

\section{Compliance with ethical standards}

Conflict of interest The authors declare that they have no conflict of interest. Part of the data in this manuscript has been presented during APBMT Congress on August 30-September 1, 2019, at Busan, South Korea.
Publisher's note Springer Nature remains neutral with regard to jurisdictional claims in published maps and institutional affiliations.

Open Access This article is licensed under a Creative Commons Attribution 4.0 International License, which permits use, sharing, adaptation, distribution and reproduction in any medium or format, as long as you give appropriate credit to the original author(s) and the source, provide a link to the Creative Commons license, and indicate if changes were made. The images or other third party material in this article are included in the article's Creative Commons license, unless indicated otherwise in a credit line to the material. If material is not included in the article's Creative Commons license and your intended use is not permitted by statutory regulation or exceeds the permitted use, you will need to obtain permission directly from the copyright holder. To view a copy of this license, visit http://creativecommons. org/licenses/by/4.0/.

\section{References}

1. Passweg JR, Halter J, Bucher C, Gerull S, Heim D, Rovó A, et al. Hematopoietic stem cell transplantation: a review and recommendations for follow-up care for the general practitioner. 2012:1-15.

2. Majhail NS, Farnia SH, Carpenter PA, Champlin RE, Crawford S, Marks DI, et al. Indications for autologous and allogeneic hematopoietic cell transplantation: guidelines from the American society for blood and marrow transplantation. Biol Blood Marrow Transplant. 2015;21:1-7.

3. Santosa D. Transplantasi Sumsum Tulang. 1st ed. Semarang: Diponegoro University Press; 2018.

4. Antin JH, Yolin Raley D. Manual of stem cell and bone marrow transplantation. Cambridge: Cambridge University Press; 2013.

5. Yeşilipek MA. Hematopoetic stem cell transplantation in children. Turk Pediatr Ars. 2014;49:91-8.

6. Hariman $\mathrm{H}$. The hematopoietic stem cell transplantation in Indonesia: an unsolved dilemma. Bone Marrow Transpl. 2008;42 (SUPPL.1):85-8.

7. Departemen Ilmu Penyakit Dalam FK UI/RS Cipto Mangunkusumo. Sejarah Perkembangan Transplantasi Sumsum Tulang di Jakarta (FKUI-RSCM) [Internet]. Available from: https://www. internafkui.or.id/?page $=$ centerofexcellent.view\&id $=5$.

8. Kota Semarang dalam Angka 2017. BPS Kota Semarang.

9. Dinas Kesehatan Propinsi Jawa Tengah. Alamat Puskesmas dan Rumah Sakit Provinsi Jawa Tengah. 2015.

10. Ratajczak L, Marlicz W, Rozmysłowicz W, Machalinski B, MZ R. Comparison of the different strategies for cryopreserving and storage of the bone marrow CD34+ cells. Possibility of unprogrammed rate freezing and storage at $-80^{\circ} \mathrm{C}$ mechanical freezer. Ann Transpl. 1996;1:35-8.

11. Galmeas A, Besalduch J, Bargay J, Matamoros N, Morey M, Novo A, et al. A simplified method for cryopreservation of hematopoietic stem cells with $-80^{\circ} \mathrm{C}$ mechanical freezer with dimethyl sulfoxide as the sole cryoprotectant. Leuk Lymphoma. 1995;17:181-4.

12. Gratama JW, Kraan J, Keeney M, Sutherland DR, Granger V, Barnett D. Validation of the single-platform ISHAGE method for CD34+ hematopoietic stem and progenitor cell enumeration in an international multicenter study. Cytotherapy. 2003;5:55-65.

13. Naithani R, Dayal N, Dixit G. Single versus dual platform analysis for hematopoietic stem cell enumeration using ISHAGE protocol. Indian J Hematol Blood Transfus. 2017;33:370-4.

14. US Department of Health and Human Services. Common Terminology Criteria for Adverse Events (CTCAE) Version 5.0. 2017. 
15. Mateos MK, O’Brien TA, Oswald C, Gabriel M, Ziegler DS, Cohn RJ, et al. Transplant-related mortality following allogeneic hematopoeitic stem cell transplantation for pediatric acute lymphoblastic leukemia: 25-year retrospective review. Pediatr Blood Cancer. 2013;60:1520-7.

16. Kedia S, Acharya PS, Mohammad F, Nguyen H, Asti D, Mehta S, et al. Infectious complications of hematopoietic stem cell transplantation. J Stem Cell Res Ther. 2013;S3:1-8.

17. Lucas AJ, Olin JL, Coleman MD. Management and preventive measures for febrile neutropenia. Pharm Ther. 2018;43:228-32.

18. Bahar B, Tormey CA. Prevention of transfusion-associated graftversus-host disease with blood product irradiation the past, present, and future. Arch Pathol Lab Med. 2018;142:662-7.

19. Weiss B, Hoffmann M, Anders C, Hellstern P, Schmitz N, Uppenkamp M. Gamma-irradiation of blood products following autologous stem cell transplantation: surveillance of the policy of 35 centers. Ann Hematol. 2004;83:44-9.

20. Gajewski JL, Johnson VV, Sandler SG, Sayegh A, Klumpp TR. A review of transfusion practice before, during, and after hematopoietic progenitor cell transplantation. Blood. 2008;112:3036-47.

21. Patel SR, Zimring JC. Transfusion-induced bone marrow transplant rejection due to minor histocompatibility antigens. Transfus Med Rev. 2013;27:241-8.

22. TRANSFORMER [Internet]. Available from: http://transplanta tionformercy.blogspot.com/2014/04/apa-itu-transformer.html.

23. Yayasan Kanker Indonesia (Indonesian Cancer Foundation) [Internet]. Available from: http://yayasankankerindonesia.org.

24. BPJS Kesehatan. BPJS Kesehatan [Internet]. Badan Penyelenggara Jaminan Sosial Kesehatan. 2019. Available from: https:// bpjs-kesehatan.go.id/bpjs/. 